\title{
Managing Rivers for Multiple Benefits-A Coherent Approach to Research, Policy and Planning
}

\author{
David Tickner ${ }^{1,2 *}$, Helen Parker ${ }^{3}$, Catherine R. Moncrieff ${ }^{1}$, Naomi E. M. Oates ${ }^{3}$, Eva Ludi ${ }^{3}$ \\ and Mike Acreman ${ }^{4}$ \\ ${ }^{1}$ Freshwater Programme, WWF-UK, Woking, UK, ${ }^{2}$ Water Security Research Centre, University of East Anglia, Norwich, UK, \\ ${ }^{3}$ Overseas Development Institute, London, UK, ${ }^{4}$ Centre for Ecology and Hydrology, Wallingford, UK
}

OPEN ACCESS

Edited by:

Anik Bhaduri,

Griffith University, Australia

Reviewed by:

Saravanan V. Subramanian, University of Bonn, Germany

Pamela A. Green, CUNY Environmental CrossRoads Initiative, USA

*Correspondence: David Tickner dtickner@wwf.org.uk

Specialty section: This article was submitted to

Freshwater Science,

a section of the journal

Frontiers in Environmental Science

Received: 17 June 2016

Accepted: 13 January 2017

Published: 03 February 2017

Citation:

Tickner D, Parker H, Moncrieff CR, Oates NEM, Ludi E and Acreman M (2017) Managing Rivers for Multiple

Benefits-A Coherent Approach to Research, Policy and Planning.

Front. Environ. Sci. 5:4 doi: 10.3389/fenvs.2017.00004
Rivers provide water for irrigation, domestic supply, power generation and industry as well as a range of other ecosystem services and intrinsic and biodiversity values. Managing rivers to provide multiple benefits is therefore foundational to water security and other policy priorities. Because river flow is often insufficient to meet all needs fully, water management experts have acknowledged the need for trade-offs in river management. Ecosystem scientists have classified and quantified goods and services that rivers provide to society. However, they have seldom examined the way in which water management infrastructure and institutional arrangements harness and direct goods and services to different groups in society. Meanwhile, water management paradigms have often considered freshwater ecosystems as rival water users to society or a source of natural hazards and have underplayed the role healthy ecosystems play in providing multiple social and economic benefits. We argue that physical and social structures and processes are necessary to realize multiple benefits from river ecosystems, and that these structures and processes, in the form of (formal and informal) institutions and (gray and green) infrastructure, shape how benefits accrue to different groups in society. We contend that institutions and infrastructure are in turn shaped by political economy. We suggest a more coherent framework for river management research, policy and planning that focuses on (a) the ways in which political economy, institutions and infrastructure mediate access and entitlements to benefits derived from ecosystem services, and (b) the feedbacks and trade-offs between investments in physical and social structures and processes.

\footnotetext{
Keywords: water security, ecosystem services, river management, infrastructure, institutions, access and entitlements, political economy
}

\section{INTRODUCTION}

The inclusion of a specific water goal within the UN Sustainable Development Goals and the establishment of a High Level Panel on Water by the UN Secretary General in 2015, reinforced the sense that water security represents a grand inter-disciplinary challenge for the research and policy communities (Matthews et al., 2011; Bunn, 2016). Commentators have previously explored the economic (World Bank, 2016; World Economic Forum, 2016), security (US Intelligence Community, 2012), social (Zeitoun et al., 2016), engineering (Royal Academy of Engineering, 2010), and environmental (Strayer and Dudgeon, 2010) dimensions of this challenge. 
Along with direct rainfall (green water), rivers, lakes, wetlands and aquifers (blue water) are primary sources of water for human consumption (Hoekstra et al., 2012). Rivers and associated wetlands also provide many other ecosystem services and hold intrinsic values for many cultures (Millennium Ecosystem Assessment, 2005). However, there is often insufficient water of adequate quality available to meet all demands fully. Resolving river management trade-offs has become harder as agricultural, industrial and urban demands have increased, leading to declining river condition in many regions (Vörösmarty et al., 2010). Climate change is likely to exacerbate these difficulties (Acreman et al., 2014; Field et al., 2014). In contexts that are dynamic and complex, strategic approaches to river management are needed that explicitly consider multiple potential uses of the river, taking account of risks and opportunities for different groups in society in different locations, while safeguarding critical ecosystem functions (Pegram et al., 2013; Speed et al., 2016). Tools and frameworks that facilitate inputs from different disciplinary and societal perspectives can support researchers, policy makers and river basin planners tackling this challenge.

This paper highlights the potential for a more coherent understanding of the connections between river condition, ecosystem services and the provision of multiple benefits to different groups in society. We highlight how these connections, and the way benefits are realized and distributed across different groups of people, are shaped by physical and social structures, rules and norms. We argue that river and water management paradigms have rarely taken sufficient account of the way in which power and politics influence these structures, rules and norms. We set out a conceptual framework for research, policy and planning that illustrates how access and entitlements to water security and other benefits from ecosystem services are mediated by institutions and infrastructure, which are in turn shaped by political economy.

\section{THE (LACK OF) DISCIPLINARY INTERFACE BETWEEN ECOSYSTEM SERVICES AND WATER SECURITY ANALYSIS}

Research on ecosystem services is summarized in authoritative reviews including those from Emerton and Bos (2004), the Millennium Ecosystem Assessment (2005) and Sukhdev et al. (2010). Ecosystem services literature has often described the gross values of provisioning, regulating, cultural or supporting services at different spatial scales and has accounted for shifts in those values arising from anthropogenic pressures (Finlayson and D'Cruz, 2005; Costanza et al., 2014). For rivers, specific examples have included monetising the value of fisheries (Butler et al., 2009; Delgado et al., 2013), the flow of goods and services from sites, such as wetlands or lakes (Zhang et al., 2014; Adekola et al., 2015) or the impacts of dam removal (Provencher et al., 2008). Findings from ecosystem services research have often been used by NGOs and others to advocate for river conservation and restoration (Auerbach et al., 2014).
Ecosystem service assessments are subject to methodological limitations relating to the spatial and temporal variation in service availability (European Environment Agency, 2010); the difficulty in quantifying biodiversity and intrinsic values (Finlayson and D'Cruz, 2005; Gowan et al., 2006); and the lack of consideration of "ecosystem dis-services," such as flooding or water-borne diseases. Some research has considered trade-offs in services resulting from different management options (Acreman et al., 2011). However, the ecosystem services literature rarely explores how services provided by rivers are harnessed and distributed among different groups in society via formal and/or informal institutional processes and infrastructure (Parker and Oates, 2016). One exception is Fisher et al. (2014) who emphasize that ecosystem services are characterized as much by human factors as by biophysical processes. Given the fundamentally political nature of natural resource allocation processes (BerbésBlázquez et al., 2016; Wyborn et al., 2016), the need to link ecosystem services to human well-being in order to influence policy (Ruckelshaus et al., 2015) and the need for equity in water security decision-making (Zeitoun et al., 2016), this suggests an overly narrow disciplinary focus among ecosystem service advocates.

Water security concepts have been analyzed through various lenses including Integrated Water Resource Management (IWRM) and Integrated River Basin Management (IRBM) approaches (Moss, 2012; Muller, 2015); macro-economic growth (Hatfield-Dodds, 2006; Grey and Sadoff, 2007; Sadoff et al., 2015); water governance (Pahl-Wostl et al., 2013; Zeitoun et al., 2013); and political economy analysis (Swatuk, 2008; Kooy and Harris, 2012; Newborne, 2014). This diversity of approaches has resulted in lively critical debate. For instance, Zeitoun et al. (2016) responded to the perceived primacy of "reductive" water security analysis (which emphasizes increased reservoir storage as a primary mechanism for reducing hydrological variability and supporting economic growth) by advocating a more "integrative" approach that recognizes diverse societal and biophysical contexts, uncertainty and adaptive management. However, the links between water security, river condition and ecosystem services have seldom been explored in detail and the implications of water management decisions on ecosystem services have been either implicit or over-looked in most water security narratives (Tickner and Acreman, 2013). When the environment has been discussed, it has often been considered a rival water user to people, with less explicit analysis of the role that functioning river ecosystems play in providing goods and services that underpin human well-being and economic development (Parker and Oates, 2016).

Thus, there are unhelpful disconnects between ecosystem services and water security framings, and between different analytical viewpoints within the water security literature. There are few empirical analyses of the complex and context-specific feedback loops between river ecosystem condition, portfolios of ecosystem services and the access and entitlements that different groups in society have to multiple river management benefits including, but not limited to, water supply. A more coherent and robust assessment of feedbacks and trade-offs that might arise from different river management measures requires a guiding 
analytical framework of these connections, drawing on different disciplines and perspectives.

\section{WHO BENEFITS, AND HOW? THE ROLE OF INFRASTRUCTURE AND INSTITUTIONS IN REALISING MULTIPLE BENEFITS FROM RIVER ECOSYSTEM SERVICES}

Unregulated, or free-flowing, rivers can provide many ecosystem services (Auerbach et al., 2014). However, in a world with more people living increasingly thirsty lifestyles, many of whom are far from the actual river, achieving water security and other benefits from river ecosystem services require intensive river management, including investment in "gray" infrastructure, such as dams, barrages and inter-basin transfers. The construction and operation of gray infrastructure brings about changes in river ecosystems and, consequently, alterations to portfolios of ecosystem services provided by "green" infrastructure (Palmer et al., 2015). Key questions for river management therefore include: (i) how best to blend gray and green infrastructure interventions to balance provision of different ecosystem services?; (ii) how to ensure that different groups in society, in different locations, have a say in the prioritization of ecosystem services?; and (iii) how can formal and informal institutional processes ensure equitable distribution of benefits across time and space?

Multiple factors contribute to whether benefits from ecosystem services are actually realized, or perceived to be realized, by different groups in society, beyond the condition of the river ecosystem itself. For example, to accrue livelihood benefits a fisherman on the Mekong River requires a boat, nets and the necessary permits or entitlements to access the river and fish. The fisherman's ability to earn income from his catch is contingent on access to markets and market prices, which in turn depend on a variety of formal and informal institutional processes. Although the context is very different, a subsistence farmer in Tanzania's Iringa District, who relies on continued flow of the Great Ruaha River as a source of water for dry season irrigation, is similarly dependent on infrastructure and institutions. Among other aspects, the farmer might require the construction and maintenance of (legal or illegal) irrigation canals and sluice gates, permits from the local Water User Association and/or the Basin Water Board (both of which might face significant capacity challenges) and a wide variety of informal interactions with neighboring farmers and other water stakeholders to ensure the flow of water between farms.

There is also a spatial dimension to consider: those close to the river, including our Mekong fisherman and Tanzanian farmer, might have a genuine claim on the ecosystem services it provides, but they may also be most exposed to the impacts of interventions elsewhere along the river, such as a dam which affects the level and timing of river flows or the development of large-scale commercial farms that are allocated priority water rights. Some benefits, such as electricity generated from hydropower dams or international tourism based on river-dependent wildlife, accrue primarily to groups beyond the river basin boundaries. Temporal factors are also important, linked to variability of river flows, daily variation in energy needs, and seasonal requirements of the agricultural calendar.

Given that rivers provide a range of benefits, and that these benefits are seldom equally distributed in society, decisions about river management necessitate trade-offs between different interests groups and policy imperatives. Asymmetries of power mean that decisions about trade-offs are rarely objective; the poor and marginalized often lose out to more influential actors (Acreman, 1996; Komakech et al., 2012). Disadvantages in access and entitlements can be exacerbated because vulnerable groups often rely disproportionately on ecosystem services, such as fisheries, particularly as a livelihood strategy of last resort (Korsgaard and Schou, 2010). Measures to enhance water security for some sections of society can lead to insecurity in supplies of water or other ecosystem services to others. This political dimension is made even more challenging if river and water management institutions are designed or operate without recognition of the often-different (e.g., farm, municipal, regional, national) scales at which other important decision-making processes operate (Zeitoun et al., 2016). Politics will always play a part in natural resource management but any framing intended to inform decisions should as far as possible encourage coherent analysis and transparent, equitable and evidence-based choices (UN Water, 2012; Pahl-Wostl et al., 2013; Hurford and Harou, 2014).

\section{A FRAMEWORK TO ENCOURAGE COHERENT RIVER MANAGEMENT RESEARCH, POLICY AND PLANNING}

In Figure 1A, we set out a conceptual framework for a coherent approach to river management research, policy and planning to encourage informed, equitable and sustainable river management. The framework shows how perspectives and information from the different disciplines and schools of thought that contribute to river management can be combined, including ecosystem services approaches (traditionally the focus of ecologists and environmental economists) and water security and water resource management approaches (historically dominated by disciplines, such as engineers, agronomists and hydrologists but increasingly including social scientists). It also introduces a strong element of political economy analysis.

Drawing on river restoration and ecosystem services approaches, the river condition component of the framework focuses on the overall health of a river ecosystem. Indicators relate to ecosystem structure and functions including catchment processes, water quality, river flows, and connectivity, biodiversity or species composition, habitat characteristics or river morphology (Finlayson and D'Cruz, 2005; Speed et al., 2016). Alterations to the condition of a river will have implications for the ecosystem services (and dis-services) it provides and the range of societal benefits that arise.

Following Fisher et al. (2009), we consider societal benefits to be distinct from ecosystem services. Whilst "ecosystem services are the aspects of ecosystems utilized (actively or passively) to 
A

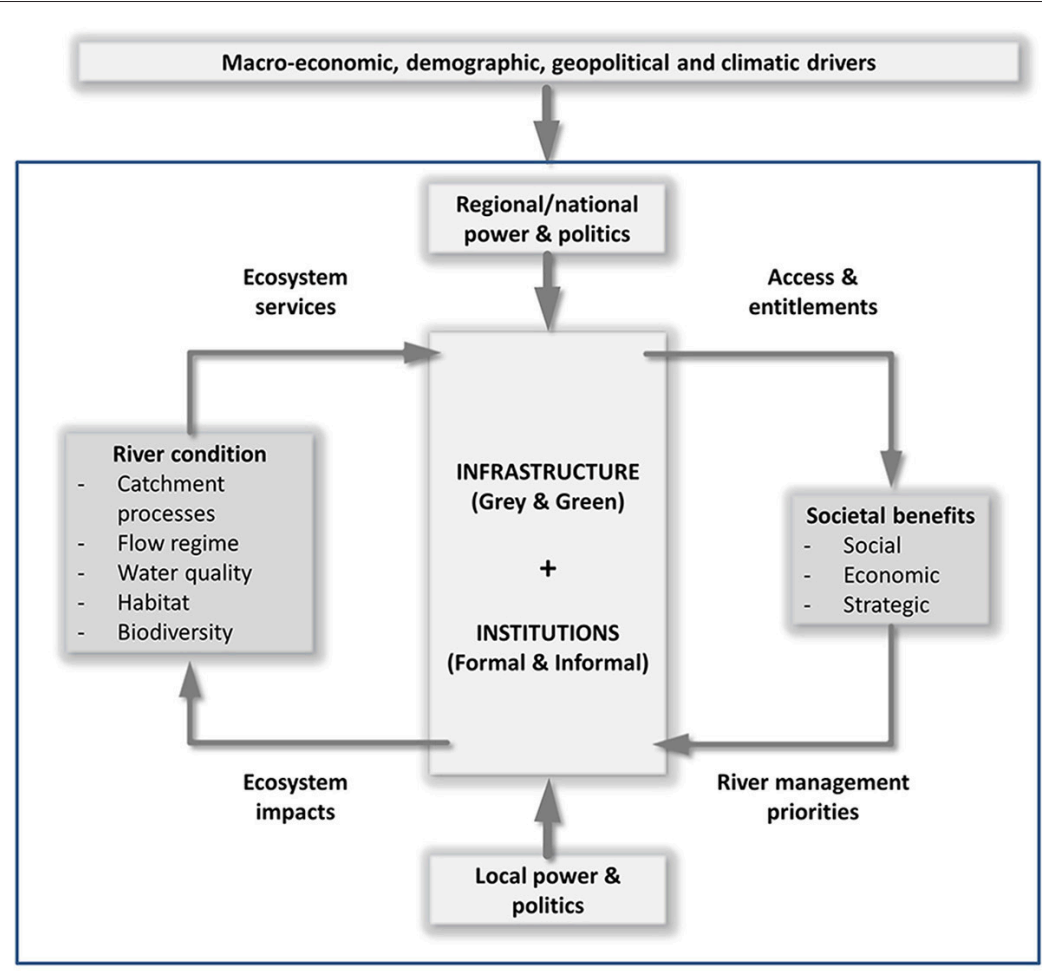

B

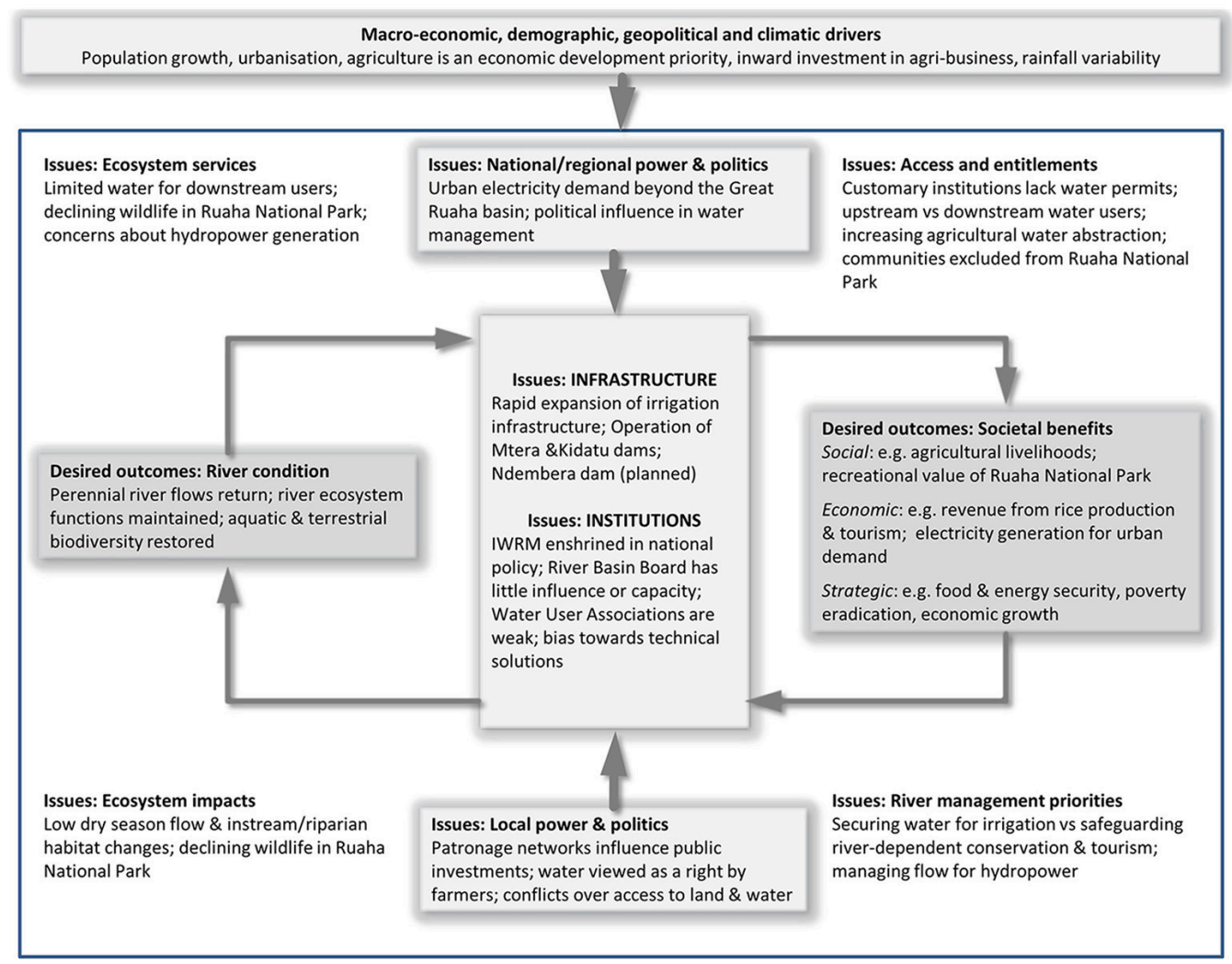

FIGURE 1 | (A) A conceptual framework for coherent research, policy and planning on river management. (B) An applied example of the conceptual framework-the Great Ruaha River basin, Tanzania. 
produce human well-being" (p.645), a benefit is best understood as "the point at which human welfare is directly affected and the point where other forms of capital (built, human, and social) are needed to realize the gain in welfare" (p.646). This distinction is important, since it challenges the assumption that improvements in river ecosystem condition and services inevitably and uniformly lead to positive outcomes for society. It also helps to guide analysis of the distribution of benefits to different stakeholders in different locations within and outside the basin. Based on Parker and Oates (2016) we define three kinds of benefits as follows (note that these are not necessarily discrete categories - there will be inter-linkages and overlaps and different kinds of benefits can manifest at different spatial or temporal scales):

- Social benefits contribute to the well-being of individuals and communities and the functioning of society. They can include secure livelihoods, health and nutrition, good social relations, science and education, mental health and spiritual satisfaction. Social benefits often accrue to those living closest to the river and directly depend on river ecosystem condition.

- Economic benefits contribute to the local or national economy and/or provide employment, for example agricultural production, energy production, industrial development, transport and tourism.

- Strategic benefits contribute to national and trans-national interests and are often highly politicized. They include regional security (e.g., reductions in transboundary conflicts or improved co-operation), water-energy-food security, disaster risk reduction and climate resilience.

Finally, any coherent approach to research, policy and planning should consider the power and politics that lie at the heart of river-society relationships. Decisions about trade-offs made by formal and/or informal institutions, and investments in gray and/or green infrastructure, deliberately or inadvertently alter portfolios of ecosystem services. A political economy analysis can illuminate potential distributional effects of river management priorities, revealing whose interests are promoted, and whose are relegated or ignored, in decision-making processes. This can facilitate transparent trade-offs between different interest groups and strategic imperatives and help to highlight specific research, policy or planning interventions that are more likely to improve outcomes for river condition and ensure equitable access and entitlements to benefits (Berbés-Blázquez et al., 2016).

Figure 1B shows how this framework could be applied to encourage coherent approaches to research, planning and management of the Great Ruaha River. A critical challenge in the Great Ruaha system is safeguarding flows through Ruaha National Park and downstream to the Mtera and Kidatu hydropower dams (Baur et al., 2000; Franks et al., 2004) which contribute significantly to Tanzania's electricity supply. The desired outcomes for river condition (at the left hand side of Figure 1B) might therefore focus primarily on the flow regime. The Great Ruaha basin is also a bread-basket for Tanzania and home to a large farming population, where small and large scale farmers depend on water allocations for subsistence and/or commercial crop production (Lankford and Franks, 2000). The social, economic and strategic outcomes (the right hand side of Figure 1B) therefore relate to specific issues of poverty reduction, agricultural sector development and food security. Energy security, linked to hydropower, is also important as a strategic outcome.

Our framework facilitates a coherent diagnosis of complex situations, such as the Great Ruaha (as summarized in Figure 1B), including the inter-connected biophysical, socioeconomic, cultural and engineering challenges. The framework can also be used to facilitate more integrated planning which takes account of the existing political, economic, infrastructure and institutional context, to achieve more balanced and equitable outcomes from river management than have hitherto been achieved. Specifically, it facilitates the identification of synergies, opportunity costs, and trade-offs between river management options, prompting questions, such as: what are the potential trade-offs and complementarities of river development and river restoration?; and, how can an equitable, efficient and sustainable allocation system which protects the most vulnerable be created? (Further questions are illustrated in Table 1) In the case of the Great Ruaha, such questions might prompt a stakeholderled environmental flow assessment to provide insights into options for achieving specific ecosystem conditions; or a refined water rights regime that upholds equitable water allocations and supports the attainment of desired outcomes.

\section{CONCLUSIONS: PUTTING THE FRAMEWORK INTO PRACTICE}

Approaches to understanding river-water-society relationships are clearly diverse, encompassing numerous branches of natural and social science with varied epistemological underpinnings. There is much useful analysis in the water security and ecosystem services literature. However, we believe that even greater insights can be gained from bringing together different schools of thought and areas of expertise to better understand complex and dynamic socio-ecological processes, and the distributional effects of river management decisions. Our framework facilitates this by integrating concepts from ecosystem science, water resource management, social science and political economy, thereby linking concerns about the river ecosystem with the concerns of decision makers-i.e., social, economic and strategic outcomes. This broader analysis supports understanding of how and why different groups within society benefit from the services a river provides. In addition, as the Great Ruaha River example illustrates, it has the potential to facilitate the design and delivery of more coherent management interventions through explicit consideration of multiple benefits from, and trade-offs between, different options, including consideration of likely winners and losers.

Supported by targeted evidence gathering to aid understanding of causal connections and feedback loops, drawing on a range of disciplines, and using language and concepts familiar to decision-makers, we hope our framework can invigorate river management efforts. As well as supporting inter-disciplinary research, this coherent 
TABLE 1 | Questions for coherent research, policy and planning in the Great Ruaha River, Tanzania.

\begin{tabular}{|c|c|}
\hline & Questions \\
\hline River condition outcomes & - What dry season flows are required to maintain critical ecosystem functions and safeguard wildlife populations? \\
\hline Societal benefit outcomes & $\begin{array}{l}\text { - What river-related social, economic and strategic benefits do different groups within and beyond the Great Ruaha River basin need? } \\
\text { - What are the potential trade-offs in provision of river-related benefits to different groups of stakeholders? }\end{array}$ \\
\hline Infrastructure and institutions & $\begin{array}{l}\text { - What infrastructure is currently used to allocate and access water from the Great Ruaha River? How is it managed? } \\
\text { - Which institutions (formal or informal) shape access to ecosystem services and the accrual of benefits? } \\
\text { - How can institutions work to strengthen governance processes for improved river management? }\end{array}$ \\
\hline Power and politics & $\begin{array}{l}\text { - What political voices and power dynamics most influence infrastructure and institutional decisions affecting the Great Ruaha River? } \\
\text { - Given the political economy in the Great Ruaha River basin, and in Tanzania more broadly, what opportunities are there to foster } \\
\text { inclusive, integrated and transparent governance processes for improved river management? }\end{array}$ \\
\hline Ecosystem services & $\begin{array}{l}\text { - Which ecosystem services from the Great Ruaha River benefit different societal groups? } \\
\text { - What aspects of river condition are critical for the provision of these ecosystem services? } \\
\text { - Wow important is river condition in realising different benefits compared to other factors (including institutions and infrastructure)? } \\
\text { - What are the potential trade-offs between different ecosystem services? }\end{array}$ \\
\hline Access and entitlements & $\begin{array}{l}\text { - Which stakeholders typically win or lose in terms of accruing river-related benefits? } \\
\text { - What rules and norms prevent or enable different groups to access ecosystem services and accrue benefits? } \\
\text { - Given the current and foreseeable institutional and infrastructure situation, how can water allocation, and other processes that } \\
\text { effect the distribution of benefits derived from the Great Ruaha River, be made as equitable, efficient and sustainable as possible? }\end{array}$ \\
\hline River management priorities & $\begin{array}{l}\text { - What are the stated priorities for river management within the Rufiji basin IWRMD plan? How do these align with current water } \\
\text { allocation regimes? } \\
\text { - What are the potential synergies and complementarities between river development and river restoration? }\end{array}$ \\
\hline Ecosystem Impacts & $\begin{array}{l}\text { - What data is available on the hydrology, fluvial geomorphology and ecology of the Great Ruaha River } \\
\text { - What are the risks and impacts on river condition of stated river management priorities and other pressures? } \\
\text { - What are the current trends in freshwater biodiversity and what is driving those trends? }\end{array}$ \\
\hline
\end{tabular}

approach could help policy makers and programme leaders in governments, multi-lateral organizations and NGOs to develop stronger theories of change linking prospective interventions and outcomes in terms of river condition and societal benefits.

\section{AUTHOR CONTRIBUTIONS}

This paper is based on research conceived by WWF-UK (DT and $\mathrm{CM}$ ), led by ODI (HP and NO) and informed by contributions from other experts (EL and MA). In this paper the authors have collectively updated the analysis from the original research report (Parker and Oates, 2016) in light of emerging literature and proposed an amended river management framework. They have also added new material, particularly with regard to the

\section{REFERENCES}

Acreman, M. (1996). Environmental effects of hydro-electric power generation in africa and the potential for artificial floods. Water Environ. J. 10, 429-435. doi: 10.1111/j.1747-6593.1996.tb 00076.x implications of the report findings for researchers, policy-makers and practitioners working on water security and freshwater conservation.

\section{FUNDING}

Some funding for work that informed this paper was provided by WWF-UK through the HSBC Water Programme.

\section{ACKNOWLEDGMENTS}

We are grateful to colleagues who provided helpful input to our research at an early stage, especially Roger Calow, Conor Linstead, and Mark Zeitoun. We would also like to thank two reviewers who provided useful comments on a draft of this paper. 
Somerset Levels and Moors wetlands. Hydrological Sci. J. 56, 1543-1565. doi: 10.1080/02626667.2011.629783

Adekola, O., Mitchell, G., and Grainger, A. (2015). Inequality and ecosystem services: the value and social distribution of Niger Delta wetland services. Ecosyst. Serv. 12, 42-54. doi: 10.1016/j.ecoser.2015.01.005

Auerbach, D. A., Deisenroth, D. B., McShane, R. R., McCluney, K. E., and Poff, N. L. (2014). Beyond the concrete: accounting for ecosystem services from free-flowing rivers. Ecosyst. Serv. 10, 1-5. doi: 10.1016/j.ecoser.2014. 07.005

Baur, P., Mandeville, N., Lankford, B., and Boake, R. (2000). "Upstream/downstream competition for water in the Usangu Basin, Tanzania," in BHS Seventh National Hydrology Symposium, (Newcastle).

Berbés-Blázquez, M., González, J. A., and Pascual, U. (2016). Towards an ecosystem services approach that addresses social power relations. Curr. Opin. Environ. Sustain. 19, 134-143. doi: 10.1016/j.cosust.2016.02.003

Bunn, S. E. (2016). Grand challenge for the future of freshwater ecosystems. Front. Environ. Sci. 4:21. doi: 10.3389/fenvs.2016.00021

Butler, J. R., Radford, A., Riddington, G., and Laughton, R. (2009). Evaluating an ecosystem service provided by Atlantic salmon, sea trout and other fish species in the River Spey, Scotland: the economic impact of recreational rod fisheries. Fish. Res. 96, 259-266. doi: 10.1016/j.fishres.2008.12.006

Costanza, R., de Groot, R., Sutton, P., van der Ploeg, S., Anderson, S. J., Kubiszewski, I., et al. (2014). Changes in the global value of ecosystem services. Glob. Environ. Change 26, 152-158. doi: 10.1016/j.gloenvcha.2014. 04.002

Delgado, L. E., Sepúlveda, M. B., and Marín, V. H. (2013). Provision of ecosystem services by the Aysén watershed, Chilean Patagonia, to rural households. Ecosyst. Serv. 5, 102-109. doi: 10.1016/j.ecoser.2013.04.008

Emerton, L., and Bos, E. (2004). Value: Counting Ecosystems as Water Infrastructure. Gland; Cambridge: IUCN. doi: 10.2305/iucn.ch.2004.wani.3.en

European Environment Agency (2010). Scaling up Ecosystem Benefits: A Contribution to The Economics of Ecosystems and Biodiversity (TEEB) Study. Copenhagen: European Environment Agency.

Field, C. B., Barros, V. R., Mach, K., and Mastrandrea, M. (2014). Climate change 2014: impacts, adaptation, and vulnerability. New York, NY: Cambridge University Press.

Finlayson, C., and D'Cruz, R. (2005). "Inland water systems," in Ecosystems and Human Well-Being: Current State and Trends, Vol. 1, Millenium Ecosystem Assessment, eds R. Hassan, R. Scholes, and N. Ash (Washington, DC: Island Press).

Fisher, B., Turner, R. K., and Morling, P. (2009). Defining and classifying ecosystem services for decision making. Ecol. Econ. 68, 643-653. doi: 10.1016/j.ecolecon.2008.09.014

Fisher, J. A., Patenaude, G., Giri, K., Lewis, K., Meir, P., Pinho, P., et al. (2014). Understanding the relationships between ecosystem services and poverty alleviation: a conceptual framework. Ecosys. Serv. 7, 34-45. doi: 10.1016/j.ecoser.2013.08.002

Franks, T., Lankford, B., and Mdemu, M. (2004). Managing water amongst competing uses: the Usangu Wetland in Tanzania. Irrigat. Drainage 53, 277-286. doi: 10.1002/ird.123

Gowan, C., Stephenson, K., and Shabman, L. (2006). The role of ecosystem valuation in environmental decision making: hydropower relicensing and dam removal on the Elwha River. Ecol. Econ. 56, 508-523. doi: 10.1016/j.ecolecon.2005.03.018

Grey, D., and Sadoff, C. W. (2007). Sink or Swim? Water security for growth and development. Water Policy 9, 545. doi: 10.2166/wp.2007.021

Hatfield-Dodds, S. (2006). Water strategies for sustainable development: What is required to ensure 'responsible growth'? Discussion Paper - A response to the 'Water for Growth and Development' theme Document from the 4th World Water Forum (CSIRO).

Hoekstra, A. Y., Mekonnen, M. M., Chapagain, A. K., Mathews, R. E., and Richter, B. D. (2012). Global monthly water scarcity: blue water footprints versus blue water availability. PLoS ONE 7:e32688. doi: 10.1371/journal.pone.0 032688

Hurford, A., and Harou, J. (2014). Balancing ecosystem services with energy and food security-assessing trade-offs for reservoir operation and irrigation investment in Kenya's Tana basin. Hydrol. Earth Syst. Sci. 11, 1343-1388. doi: 10.5194/hessd-11-1343-2014

Komakech, H. C., Van Der Zaag, P., and Van Koppen, B. (2012). The last will be first: water transfers from agriculture to cities in the Pangani river basin, Tanzania. Water Altern. 5, 700. Available online at: http://www.wateralternatives.org/index.php/volume5/v5issue3/193-a5-3-9/file

Kooy, M., and Harris, D. (2012). Political Economy Analysis for Water, Sanitation and Hygiene (WASH) Service Delivery. Overseas Development Institute (ODI), London, UK, p. 4. ODI Project Briefing No. 77.

Korsgaard, L., and Schou, J. S. (2010). Economic valuation of aquatic ecosystem services in developing countries. Water Policy 12, 20-31. doi: 10.2166/wp.2009.124

Lankford, B., and Franks, T. (2000). The sustainable coexistence of wetlands and rice irrigation: a case study from Tanzania. J. Environ. Dev. 9, 119-137. doi: 10.1177/107049650000900202

Matthews, J. H., Wickel, B. A., and Freeman, S. (2011). Converging currents in climate-relevant conservation: water, infrastructure, and institutions. PLoS Biol. 9:e1001159. doi: 10.1371/journal.pbio.1001159

Millennium Ecosystem Assessment (2005). Ecosystems and Human Well-Being: Wetlands and Water. Washington, DC: World Resources Institute.

Moss, T. (2012). Spatial fit, from panacea to practice: implementing the EU Water Framework Directive. Ecol. Soc. 17, 2. doi: 10.5751/ES-04821-170302

Muller, M. (2015). The 'Nexus' As a Step Back towards a More Coherent Water Resource Management Paradigm. Water Altern. 8, 675-694. Available online at: http://www.water-alternatives.org/index.php/all-abs/271-a8-1-4/file

Newborne, P. (2014). Advancing Hydropower Sustainability: From Project Design to Sector Planning. Overseas Development Institute (ODI). London, UK. p. 8. ODI Development Progress Discussion Paper 02.

Pahl-Wostl, C., Palmer, M., and Richards, K. (2013). Enhancing water security for the benefits of humans and nature-the role of governance. Curr. Opin. Environ. Sustain. 5, 676-684. doi: 10.1016/j.cosust.2013.10.018

Palmer, M. A., Liu, J., Matthews, J. H., Mumba, M., and D’Odorico, P. (2015). Manage water in a green way. Science 349, 584-585. doi: 10.1126/science.aac7778

Parker, H., and Oates, N. (2016). How do Healthy Rivers Benefit Society? A Review of the Evidence. London: ODI and WWF.

Pegram, G., Yuanyuan, L., Le Quesne, T., Speed, R., Jianqiang, L., and Fuxin, S. (2013). River Basin Planning Principles: Procedures and Approaches for Strategic Basin Planning. Paris: UNESCO.

Provencher, B., Sarakinos, H., and Meyer, T. (2008). Does small dam removal affect local property values? An empirical analysis. Contemp. Econ. Policy 26, 187-197. doi: 10.1111/j.1465-7287.2008.00107.x

Royal Academy of Engineering (2010). Global Water Security: An Engineering Perspective. London: Royal Academy of Engineering.

Ruckelshaus, M., McKenzie, E., Tallis, H., Guerry, A., Daily, G., Kareiva, P., et al. (2015). Notes from the field: lessons learned from using ecosystem service approaches to inform real-world decisions. Ecol. Econ. 115, 11-21. doi: 10.1016/j.ecolecon.2013.07.009

Sadoff, C., Hall, J., Grey, D., Aerts, J. C., Ait-Kadi, M., Brown, C., et al. (2015). Securing Water, Sustaining Growth: Report of the GWP/OECD Task Force on Water Security and Sustainable Growth. Oxford: University of Oxford.

Speed, R., Li, Y., Tickner, D., Huang, H., Naiman, R., Yu, L., et al. (2016). River Restoration: A Strategic Approach to Planning and Management. Paris: UNESCO.

Strayer, D. L., and Dudgeon, D. (2010). Freshwater biodiversity conservation: recent progress and future challenges. J. North Am. Benthol. Soc. 29, 344-358. doi: 10.1899/08-171.1

Sukhdev, P., Wittmer, H., Schröter-Schlaack, C., Nesshöver, C., Bishop, J., ten Brink, P., et al. (2010). The Economics of Ecosystems and Biodiversity: Mainstreaming the Economics of Nature: A Synthesis of the Approach, Conclusions and Recommendations of TEEB. TEEB.

Swatuk, L. A. (2008). A political economy of water in Southern Africa. Water Alternatives 1, 24. Available online at: http://www.water-alternatives.org/index. php/volume1/v1issue1/16-a-1-1-3/file

Tickner, D., and Acreman, M. (2013). "Water security for ecosystems, ecosystems for water security," Water Security: Principles, Perspectives and Practices, eds B. 
Lankford, K. Bakker, M. Zeitoun, and D. Conway (Abingdon, UK: Routledge), 130.

UN Water (2012). Managing Water Under Uncertainty and Risk, The United Nations World Water Development Report 4. UN Water Reports, World Water Assessment Programme. UNESCO, Paris, France.

US Intelligence Community (2012). Global Water Security. Washington, DC.

Vörösmarty, C. J., McIntyre, P. B., Gessner, M. O., Dudgeon, D., Prusevich, A., Green, P., et al. (2010). Global threats to human water security and river biodiversity. Nature 467, 555-561. doi: 10.1038/nature09440

World Bank (2016). High and Dry: Climate Change, Water, and the Economy. Washington DC: World Bank.

World Economic Forum (2016). The Global Risks Report 2016. Geneva: World Economic Forum.

Wyborn, C., van Kerkhoff, L., Dunlop, M., Dudley, N., and Guevara, O. (2016). Future oriented conservation: knowledge governance, uncertainty and learning. Biodiversity Conserv. 25, 1401-1408. doi: 10.1007/s10531-016-1130-x

Zeitoun, M., Goulden, M., and Tickner, D. (2013). Current and future challenges facing transboundary river basin management. Wiley Interdiscipl. Rev. 4, 331-349. doi: $10.1002 /$ wcc. 228
Zeitoun, M., Lankford, B., Krueger, T., Forsyth, T., Carter, R., Hoekstra, A., et al. (2016). Reductionist and integrative research approaches to complex water security policy challenges. Glob. Environ. Change 39, 143-154. doi: 10.1016/j.gloenvcha.2016.04.010

Zhang, Y., Zhou, D., Niu, Z., and Xu, F. (2014). Valuation of lake and marsh wetlands ecosystem services in China. Chin. Geogr. Sci. 24, 269-278. doi: $10.1007 / \mathrm{s} 11769-013-0648-\mathrm{Z}$

Conflict of Interest Statement: The authors declare that the research was conducted in the absence of any commercial or financial relationships that could be construed as a potential conflict of interest.

Copyright (c) 2017 Tickner, Parker, Moncrieff, Oates, Ludi and Acreman. This is an open-access article distributed under the terms of the Creative Commons Attribution License (CC BY). The use, distribution or reproduction in other forums is permitted, provided the original author(s) or licensor are credited and that the original publication in this journal is cited, in accordance with accepted academic practice. No use, distribution or reproduction is permitted which does not comply with these terms. 